\title{
Pengasuhan Manajemen Kewirausahaan melalui Pelatihan Pembuatan Sabun Aroma Terapi dari Limbah Kulit Jeruk
}

\section{Parenting of Entrepreneurship Management through Training of Making of Aroma Soap from Citrus Skin Waste}

\author{
Eli Rohaeti, Sulistyani, dan Dewi Yuanita Lestari
}

\author{
Jurusan Pendidikan Kimia FMIPA UNY Karangmalang Yogyakarta 55281 \\ *E-mail: eli_rohaeti@uny.ac.id
}

\begin{abstract}
Abstrak
Kegiatan penyuluhan dan pelatihan melalui $\mathrm{PkM}$ ini bertujuan untuk memberikan pengetahuan tentang cara pembuatan sabun mandi aroma terapi dari limbah kulit jeruk pada pemuda Kampung Pingit, menjelaskan manfaat pengolahan limbah kulit jeruk menjadi sabun mandi aroma terapi, dan memotivasi pemuda Kampung Pingit untuk membuat usaha pembuatan sabun mandi aroma terapi. Kegiatan PkM ditujukan bagi kelompok Muda Mudi Mesjid Al-Manshurin Kampung Pingit, Kelurahan Bumijo, Kecamatan Jetis, Kodya Yogya. Melalui koordinasi dengan Ketua Muda Mudi Mesjid Al-Manshurin Kampung Pingit, sebanyak 48 anggota kelompok muda mudi Kampung Pingit diundang dalam pelatihan ini. Metode yang digunakan dalam kegiatan PkM ini adalah ceramah, diskusi, dan demonstrasi tentang cara pembuatan sabun mandi aroma terapi, manfaat pengolahan kulit jeruk menjadi minyak atsiri sebagai bahan baku pembuatan sabun mandi aroma terapi, serta kiat untuk melakukan wirausaha di bidang pembuatan sabun mandi aroma terapi meliputi modal yang dibutuhkan, teknik pengemasan, serta strategi pemasaran. Berdasarkan evaluasi proses dan produk serta diskusi dengan peserta pelatihan kegiatan PPM dapat disimpulkan bahwa seluruh pemuda Kampung Pingit peserta kegiatan pengasuhan manajemen kewirausahaan mengungkap bahwa kegiatan PPM tentang cara pembuatan sabun mandi aroma terapi dari limbah kulit jeruk dapat memberikan bekal pengetahuan dan pemahaman tentang pembuatan sabun mandi aroma terapi. Sebanyak 100\% peserta pelatihan menyatakan bahwa kegiatan pengasuhan manajemen kewirausahaan pengolahan limbah kulit jeruk menjadi sabun mandi aroma terapi dapat memberikan manfaat kepada mereka. Sebanyak $91 \%$ peserta pelatihan menyatakan bahwa kegiatan pengasuhan manajemen kewirausahaan ini mampu memotivasi pemuda Kampung Pingit untuk mencoba sendiri dan sebanyak $80 \%$ peserta pelatihan menyatakan bahwa kegiatan PPM tersebut dapat memotivasi mereka untuk berwirausaha membuat usaha pembuatan sabun mandi aroma terapi.
\end{abstract}

Kata kunci: limbah kulit jeruk, pengasuhan, dan sabun aroma terapi

\begin{abstract}
Extension and training activities through PkM aimed to provide knowledge on how to make aromatherapy bath soap from citrus peel waste in Pingit Village youth, to explain the benefits of citrus skin processing waste into aromatherapy soap, and to motivate the youth in Pingit Village to make a bath soap making business aroma therapy. The activities of PkM were aimed at youths in Mesjid AlManshurin Kampung Pingit, Bumijo, Jetis, Yogya. In coordination with the Chairman of Muda Mudi Mesjid Al-Manshurin of Pingit Village, 48 members of the young in village group were invited to this training. The methods used in this PkM activity were lectures, discussions, and demonstrations on how to make aromatherapy soap, the benefits of citrus skin processing into essential oil as a raw material for aromatherapy soaps, and tips for entrepreneurship in aromatherapy soap making including the required capital, packaging techniques, and marketing strategies. Based on the evaluation of the process and product and discussion with the participants of the PkM activity, it can be concluded that all youth participated in entrepreneurial management activities revealed that the PkM activities on how to make aromatherapy soap bath from orange peel waste can provide knowledge and understanding about making aroma bath soap therapy. As many as 100\% of trainees stated that the entrepreneurial management activities of citrus skin processing waste into aromatherapy soap can
\end{abstract}


benefit them. As many as $91 \%$ of the participants stated that this entrepreneurial management activity is able to motivate the youth to try their own and as many as $80 \%$ of the participants stated that the PkM activities can motivate them to make entrepreneurial effort to make aromatherapy bath soap.

Keywords: citron skin waste, parenting, and aromatherapy soap

\section{PENDAHULUAN}

Perkembangan jumlah populasi manusia di dunia pada era abad 21 semakin meningkat, termasuk juga di Indonesia. Jumlah penduduk Indonesia pada sensus penduduk 2010 sudah mencapai lebih dari 400 juta jiwa, sebanyak 49,79\% penduduk tinggal di daerah perkotaan dan 50,21\% penduduk tinggal di daerah pedesaan, sebanyak $89,73 \%$ penduduk berusia 15 tahun ke atas, dengan penduduk berusia angkatan kerja sebanyak 107,7 juta jiwa (Badan Pusat Statistik, 2010). Seiring dengan perkembangan populasi yang tumbuh dengan semakin pesatnya, semakin tinggi pula tingkat pengangguran manusia pada usia produktif karena kesulitan mencari lapangan pekerjaan. Tentu saja ini menjadi suatu permasalahan yang sangat sulit dipecahkan pemerintah, banyak individu atau kelompok-kelompok masyarakat yang memberatkan permasalahan tersebut kepada pemerintah, padahal pemerintah sendiri telah banyak mencanangkan program-program kewirausahaan (Kemenperin RI, 2016). Seharusnya permasalahan tersebut bukan hanya tugas pemerintah terhadap masyarakat untuk menyediakan lapangan kerja, tetapi tugas masyarakat sendiri (Tanoto Foundation, 2015).

Mencari pekerjaan memang sulit, tetapi sebagai masyarakat modern sudah sepatutnya berfikir panjang dan dewasa terhadap permasalahan lapangan pekerjaan. Seseorang mencari pekerjaan untuk dapat bertahan hidup dan juga memperbaiki kualitas ekonomi individu ataupun keluarga. Sebagai masyarakat yang modern, apalagi seorang yang berpendidikan, jangan hanya mencari pekerjaan, tetapi juga harus bisa menciptakan lapangan pekerjaan dengan berwirausaha. Sebuah bangsa bisa maju, jika wirausahanya maju. Sebagaimana dibuktikan oleh negara-negara maju di dunia, diantaranya Amerika, Singapura, dan beberapa negara-negara maju lainnya.mereka bisa maju karena masyarakat negara tersebut banyak yang berwirausaha. Seharusnya setiap masyarakat harus memiliki mental wirausahawan, jangan hanya menjadi mental pekerja saja. Dengan sebuah ide yang inovatif, maka produktivitas dapat terwujud sehingga wirausaha dan pasar baru dapat terwujud (Tanoto Foundation, 2015).

Kemampuan berwirausaha dapat diperoleh dari berbagai pelatihan-pelatihan, seminar, atau dengan berinteraksi langsung kepada para pelaku wirausaha. Dengan melakukan hal-hal tersebut maka dapat diperoleh ilmu serta pelajaran wirausaha dan langsung bisa terjun ke dalam dunia usaha sangat luas. Jika setiap masyarakat sadar akan pentingnya wirausaha, tentu saja dapat menekan jumlah pengangguran di Indonesia.

Meningkatkan mental generasi muda dalam berwirausaha adalah salah satu cara untuk membangun jiwa enterpreneur yang tangguh. Walaupun seseorang memahami strategi wirausaha tetapi kalau tidak berani terjun ke dalam dunia usaha, maka proses wirausaha pun tidak akan terwujud. Banyak yang takut akan ketatnya persaingan dengan perusahaan asing yang bermodal besar, sehingga menciutkan mental dari para enterpreneur muda Indonesia. Sebenarnya, persaingan terjadi bukan untuk saling menjatuhkan antar pengusaha, tetapi persaingan terjadi untuk lebih memotivasi para pengusaha tersebut untuk lebih berinovasi dalam hasil produksi, distribusi, dan pemasarannya. 
Pemuda Indonesia khususnya pelajar dan mahasiswa perguruan tinggi dipersiapkan untuk menjadi karyawan handal di sektor lapangan kerja umum, seperti pegawai swasta atau tentunya pegawai negeri sipil dan bekerja pada institusi tertentu, bahkan sebagian orang beranggapan bahwa sukses itu adalah apabila seorang menjadi pegawai negeri sipil dan memegang jabatan tinggi dan tentunya arah untuk menjadi seorang pekerja yang memiliki atasan, bukan sebagai seseorang yang dapat mengelola bidang usaha secara mandiri. Kenyatannya sekarang tidak berjalan mudah seperti dulu, semakin banyak orang yang ingin menjadi PNS maka semakin kecil pula kesempatan untuk memperebutkannya karena persaingan yang semakin ketat.

Kewirausahaan merupakan salah satu sifat atau teladan yang dibutuhkan oleh pemuda Indonesia, sifat ini menjadikan sesorang tidak selalu bergantung pada pemerintah untuk menjadi pegawai negeri tetapi dapat belajar mandiri, membina suatu bidang penghasilan yang mengantarkan seseorang kepada bentuk pengelolaan yang justru membuka peluang pekerjaan untuk orang banyak, peluang ini tentunya bisa mengurangi pengangguran yang dari dulu menjadi beban tersendiri bagi bangsa (Rifki Yakub, 2015).

Satu wilayah di Indonesia yang mayoritas penduduknya berusia produktif adalah Kampung Pingit. Kampung ini merupakan bagian dari Kelurahan Bumijo Kecamatan Jetis Kodya Yogya. Sebagian besar penduduk asal Kampung Pingit bermatapencaharian dengan penghasilan tidak tetap. Dalam upaya meningkatkan tingkat perekonomian warga Kampung Pingit maka perlu dilakukan pengasuhan manajemen kewirausahaan melalui berbagai pelatihan yang produktif untuk meningkatkan kemandirian dalam berusaha untuk memenuhi kebutuhan hidupnya. Kewirausahaan menjadikan sesorang menjadi sosok pemimpin idola bagi bangsa, mandiri, telaten dan tentunya sosok pekerja keras karena telah merintis dari bawah secara perlahan hingga menjadi tinggi sampai sukses, bukan sekedar diangkat menjadi pegawai langsung, dari perjalanan jauh dan panjang tersebut para entrepreneur tentunya mendapat lebih banyak pelajaran bagaimana membangun dengan lebih baik, berani mengambil resiko untuk kemakmuran yang lebih baik, serta tegas dalam mengambil keputusan.

Salah satu cara pengasuhan manajemen kewirausahaan kepada para pemuda di Kampung Pingit dapat dilakukan melalui kegiatan pelatihan pembuatan suatu produk yang bernilai guna dan dapat meningkatkan penghasilan serta tingkat perekonomian warga pada umumnya. Salahsatu produk yang bernilai guna dan dibutuhkan oleh setiap manusia adalah sabun. Pembuatan sabun dapat dilakukan dengan menambahkan suatu bahan aditif berbasis limbah menjadi minyak atsiri sehingga dapat dihasilkan sabun aroma terapi. Aroma terapi ialah istilah generik bagi salah satu jenis pengobatan alternatif yang menggunakan bahan cairan tanaman yang mudah menguap, dikenal sebagai minyak esensial, dan senyawa aromatik lainnya dari tumbuhan yang bertujuan untuk mempengaruhi suasana hati atau kesehatan seseorang, yang sering digabungkan dengan praktik pengobatan alternatif dan kepercayaan kebatinan (Sharma, 2009).

Kulit jeruk sisa dari industri pengolahan jeruk atau konsumsi masyarakat hanya dibuang tanpa pengolahan sehingga menjadi limbah organik yang menimbulkan bau ketika sudah membusuk. Kulit jeruk mempunyai komponen kimia yang membuat kulit jeruk memiliki aroma yang harum dan segar (Istianto dan Muryati, 2014). Aroma harum dan segar yang dihasilkan kulit jeruk bisa dimanfaatkan sebagai aroma terapi. Pembuatan sabun aroma terapi dengan penambahan minyak atsiri dari limbah kulit jeruk dapat dilakukan dengan mudah serta sebagai upaya mengelola limbah kulit jeruk yang dihasilkan. Selain itu, pembuatan sabun aroma terapi tidak membutuhkan biaya besar sehingga biaya produksi dalam 
pembuatan sabun aroma terapi ini relatif murah.

Berdasarkan analisis situasi, maka identifikasi permasalahan dalam kegiatan pengabdian adalah sebagai berikut:

1. Tingginya tingkat pengangguran manusia pada usia produktif karena kesulitan mencari lapangan pekerjaan

2. Para pemuda belum dapat menciptakan lapangan pekerjaan dengan berwirausaha

3. Para pemuda belum memiliki kemampuan berinovasi dalam hasil produksi, distribusi, dan pemasaran produk

4. Kulit jeruk sisa dari industri pengolahan jeruk atau konsumsi masyarakat hanya dibuang tanpa pengolahan sehingga menjadi limbah organik yang menimbulkan bau ketika sudah membusuk

5. Para pemuda belum termotivasi untuk membuat usaha pembuatan sabun mandi aroma terapi

Kegiatan penyuluhan dan pelatihan melalui PkM ini bertujuan untuk:

1. Memberikan pengetahuan tentang cara pembuatan sabun mandi aroma terapi dari limbah kulit jeruk pada pemuda Kampung Pingit.

2. Menjelaskan manfaat pengolahan limbah kulit jeruk menjadi sabun mandi aroma terapi.

3. Memotivasi pemuda Kampung Pingit untuk membuat usaha pembuatan sabun mandi aroma terapi.

\section{SOLUSI/TEKNOLOGI}

Kegiatan PkM ini ditujukan bagi kelompok Muda Mudi Mesjid Al-Manshurin Kampung Pingit, Kelurahan Bumijo, Kecamatan Jetis, Kodya Yogya. Melalui koordinasi dengan Ketua Muda Mudi Mesjid Al-Manshurin Kampung Pingit, sebanyak 48 anggota kelompok muda mudi Kampung Pingit diundang dalam pelatihan ini. Peserta yang diundang dalam pelatihan ini diharapkan mampu menularkan dan menyebarluaskan pengetahuan yang sudah diperolehnya kepada tetangga atau pemuda yang lain.

Metode yang digunakan dalam kegiatan PkM ini adalah ceramah, diskusi, dan demonstrasi tentang cara pembuatan sabun mandi aroma terapi, manfaat pengolahan kulit jeruk menjadi minyak atsiri sebagai bahan baku pembuatan sabun mandi aroma terapi, serta kiat untuk melakukan wirausaha di bidang pembuatan sabun mandi aroma terapi meliputi modal yang dibutuhkan, teknik pengemasan, serta strategi pemasaran. Selain itu juga dilakukan demo dan praktek pembuatan sabun mandi aroma terapi sehingga warga benar-benar mengerti dan dapat mempraktekkan cara pembuatannya.

Realisasi pemecahan masalah berupa kegiatan pelatihan pembuatan sabun mandi aroma terapi dari limbah kulit jeruk. Adapun rincian kegiatan pelatihan adalah sebagai berikut:

Nama Kegiatan:

Pengasuhan Manajemen Kewirausahaan melalui Pelatihan Pembuatan Sabun Aroma Terapi dari Limbah Kulit Jeruk. Waktu: Senin, 28 Agustus 2017. Tempat : Kampung Pingit JTI/304 RT 16 RW 04 Kelurahan Bumijo Kecamatan Jetis Yogyakarta. Peserta: Kelompok Muda - Mudi Kampung Pingit berjumlah 48 orang.

Materi pelatihan berupa:

1. Penyuluhan tentang minyak atsiri dan pengelolaan limbah kulit jeruk menjadi minyak atsiri oleh Sulistyani, M.Si.

2. Penyuluhan tentang metode pembuatan sabun mandi dari limbah kulit jeruk oleh Dr. Eli Rohaeti

3. Penyuluhan tentang cara pengemasan dan strategi pemasaran sabun aroma terapi oleh Dewi Yuanita Lestari, M. Sc.

Metode: ceramah, diskusi informasi, demonstrasi dan latihan pembuatan sabun mandi aroma terapi dari kulit jeruk

Langkah-langkah yang dilakukan pada pelatihan pembuatan produk sabun aroma terapi dari limbah kulit jeruk meliputi: 
a. Koordinasi dengan Ketua Tim Muda Mudi Al Manshurin Kampung Pingit untuk mengetahui jumlah pemuda yang aktif mengikuti berbagai kegiatan yang diagendakan oleh kampung, tingkat pendidikan pemuda, mata pencaharian, serta tingkat kemandiriannya. Selain itu dijajaki dan koordinasi tempat untuk kegiatan pelatihan yang direncanakan.

b. Penyuluhan tentang minyak atsiri dan pengelolaan limbah kulit jeruk menjadi minyak atsiri

c. Penyuluhan tentang metode pembuatan sabun mandi dari limbah kulit jeruk

d. Penyuluhan tentang cara pengemasan dan strategi pemasaran sabun aroma terapi

e. Praktek pembuatan sabun mandi aroma terapi

f. Pengasuhan pembuatan sabun mandi aroma terapi, pengemasan, dan pemasarannya

g. Evaluasi

h. Evaluasi kegiatan pengabdian kepada masyarakat ini meliputi evaluasi proses dan evaluasi produk kegiatan. Evaluasi proses meliputi evaluasi kemampuan penguasaan peserta terhadap materi pelatihan, manfaat materi pelatihan, motivasi mencoba sendiri, dan motivasi untuk berwirausaha. Evaluasi produk meliputi evaluasi terhadap produk sabun yang dihasilkan yaitu uji kualitas produk sabun yang dihasilkan, yaitu tekstur yang licin, padat, mempunyai wangi yang khas, menghasilkan busa, tidak menimbulkan iritasi pada kulit dan mempunyai sifat membersihkan kotoran atau lemak.

Indikator ketercapaian dilihat dari:

a. Lebih dari $90 \%$ pemuda di Kampung Pingit memahami materi pelatihan

b. Lebih dari $75 \%$ peserta berhasil mempraktekkan pembuatan sabun mandi aroma terapi dari kulit jeruk

c. Lebih dari $10 \%$ peserta memiliki motivasi untuk merintis wirausaha baru di bidang pembuatan sabun mandi aroma terapi.

\section{HASIL DAN DISKUSI}

Sebelum kegiatan pengabdian dimulai, perwakilan peserta pelatihan diberi kesempatan untuk menyampaikan keinginannya tentang materi dan metode kegiatan pelatihan. Berdasarkan kegiatan pendahuluan yang dilakukan dapat diketahui bahwa peserta menginginkan beberapa hal sebagai berikut:

1. Pembahasan tentang aroma terapi dan minyak atsiri

2. Demonstrasi cara mengolah limbah kulit jeruk

3. Pengelolaan bahan-bahan untuk membuat sabun

4. Demonstrasi cara membuat sabun mandi aroma terapi

5. Praktek cara membuat sabun mandi aroma terapi

Kegiatan pengabdiaan yang telah dilakukan menghasilkan bentuk fisik berupa sabun mandi aroma terapi. Tingkat keberhasilan kegiatan PPM ini dapat dilihat dari hasil angket untuk menilai proses pelatihan dengan hasil seperti ditunjukkan pada Tabel 1.

Tabel 1. Hasil Angket Evaluasi Proses Kegiatan Pelatihan

\begin{tabular}{|c|c|c|}
\hline No & Aspek Penilaian & $\begin{array}{c}\text { Persentase } \\
\text { Peserta (\%) }\end{array}$ \\
\hline 1 & $\begin{array}{c}\text { Pemahaman tentang } \\
\text { materi pelatihan }\end{array}$ & 100 \\
\hline 2 & $\begin{array}{c}\text { Manfaat kegiatan } \\
\text { pelatihan }\end{array}$ & 100 \\
\hline 3 & $\begin{array}{c}\text { Motivasi untuk } \\
\text { mencoba sendiri }\end{array}$ & 80 \\
\hline 4 & $\begin{array}{c}\text { Motivasi untuk } \\
\text { berwirausaha }\end{array}$ & \\
\hline
\end{tabular}

Berdasarkan Tabel 1 dapat diungkap bahwa sebanyak $100 \%$ peserta pelatihan menyatakan bahwa mereka memahami semua materi pelatihan dan kegiatan pelatihan tersebut bermanfaat bagi mereka. Hal ini karena peserta meyakini masingmasing aroma dalam aroma terapi tersebut memiliki berbagai fungsi yang tidak hanya berguna untuk mengharumkan ruangan atau wewangian namun juga memiliki berbagai fungsi luar biasa bagi kesehatan manusia (Fomari et al., 2012). Kemudian, sebanyak 91\% peserta pelatihan menyatakan bahwa mereka termotivasi untuk membuat sendiri sabun mandi aroma terapi di rumah untuk digunakan sendiri dan keluarga. Hal ini disebabkan peserta yakin bahwa bahan aktif 
tanaman berkhasiat obat. Beberapa contoh tanaman sumber minyak atsiri yang tumbuh di Indonesia dan bagian tanaman mengandung minyak atsiri dan berkhasiat obat (Muchlis Bastian, 2015).

Sebanyak $80 \%$ peserta termotivasi untuk merintis wirausaha pembuatan sabun mandi aroma terapi. Para peserta mengungkap bahwa aroma yang dikeluarkan oleh limbah kulit jeruk dengan mudah untuk diisolasinya melalui teknik press dingin. Haminuddin et al. (2010) mengungkapkan bahwa aroma tanaman dapat diisolasi melalui teknik cold press. Metode untuk memperoleh minyak atsiri dapat dilakukan secara destilasi, ekstraksi (Susanto dan Saroh, 2013), pengepresan, hidrolisis glikosida, serta teknik menggunakan adsorben (Siswati et al., 2016). Peningkatan pengetahuan dan keterampilan peserta pelatihan dapat diketahui dari kemampuannya dalam membuat sabun mandi aroma terapi. Adapun hasil evaluasi produk pelatihan diungkap pada Tabel 2 . Kegiatan dapat dikatakan berhasil jika peserta mampu membuat sabun aroma terapi secara mandiri setelah pelatihan tanpa bimbingan penyuluh Kemampuan peserta melakukan secara mandiri termasuk kategori Cukup. Di antara peserta masih perlu bimbingan dalam pembuatan sabun mandi aroma terapi tersebut. Bentuk produk harus sesuai dangan tujuan berwirausaha, maka produk harus memiliki bentuk yang baik yaitu sabun tidak mudah hancur dan kemasan menarik agar memiliki nilai jual. Bentuk dan kemasan produk yang dihasilkan peserta termasuk kategori Cukup. Bentuk sabun yang dihasilkan sudah cukup baik namun kemasannya yang perlu ditingkatkan melalui bimbingan. Kualitas Produk sabun yang dihasilkan peserta termasuk kategori Baik. Kualitas sabun yang dihasilkan diuji secara sederhana, yaitu tekstur yang licin, padat, mempunyai wangi yang khas, menghasilkan busa, tidak menimbulkan iritasi pada kulit dan mempunyai sifat membersihkan kotoran atau lemak.
Tabel 2. Hasil Evaluasi Produk Pelatihan

\begin{tabular}{|l|c|c|c|}
\hline \multirow{2}{*}{$\begin{array}{l}\text { Aspek yang } \\
\text { diamati }\end{array}$} & \multicolumn{3}{|c|}{ Kriteria } \\
\cline { 2 - 4 } $\begin{array}{l}\text { Kemampuan } \\
\text { peserta } \\
\text { melakukan } \\
\text { secara } \\
\text { mandiri }\end{array}$ & & Cukup & Kurang \\
\hline $\begin{array}{l}\text { Bentuk dan } \\
\text { kemasan } \\
\text { produk }\end{array}$ & & $\sqrt{ }$ & \\
\hline $\begin{array}{l}\text { Kualitas } \\
\text { produk }\end{array}$ & $\sqrt{ }$ & & \\
\hline
\end{tabular}

Dengan demikian Kegiatan PPM yang dilakukan sudah sesuai dengan tujuan yang diharapkan dan sudah memenuhi indikator ketercapaian dilihat dari pemahaman peserta terhadap materi pelatihan, kemampuan peserta mempraktekkan pembuatan sabun mandi aroma terapi dari kulit jeruk serta motivasi peserta untuk merintis wirausaha baru di bidang pembuatan sabun mandi aroma terapi. Sebanyak $100 \%$ peserta memahami materi pelatihan (indikator ketercapaian: lebih dari $90 \%$ pemuda di Kampung Pingit memahami materi pelatihan). Sebanyak 91\% peserta termotivasi untuk membuat sabun mandi aroma terapi sendiri di rumah (indikator ketercapaian: lebih dari $75 \%$ peserta berhasil mempraktekkan pembuatan sabun mandi aroma terapi dari kulit jeruk). Sebanyak $80 \%$ peserta termotivasi untuk merintis usaha baru di bidang pembuatan sabun mandi aroma terapi (indikator ketercapaian: lebih dari $10 \%$ peserta memiliki motivasi untuk merintis wirausaha baru di bidang produksi sabun mandi aroma terapi).

Selanjutnya, sebagai tindak lanjut dari kegiatan pengabdian ini, peserta menghendaki beberapa hal antara lain:

(1) diadakan kegiatan cara pembuatan sabun mandi aroma terapi dengan jumlah peserta lebih banyak dan durasi kegiatan lebih lama

(2) kegiatan dilaksanakan secara berkelanjutan 
(3) kegiatan praktek pembuataan sabun mandi aroma terapi dilakukan lebih lama menggunakan ekstrak tanaman/sayuran yang bervariasi

(4) perlu sosialisasi ke khalayak sasaran lebih luas

(5) diadakan kegiatan serupa untuk membuat produk cara membuat parfum dan sabun cair

(6) diadakan kegiatan lebih rutin

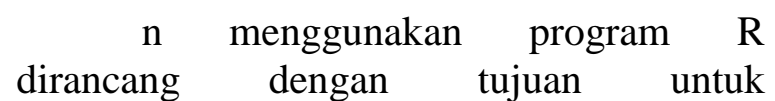
memperkenalkan program tak berbayar R, sehingga dapat menggantikan program berbayar seperti SPSS dan MINITAB yang selama ini banyak digunakan oleh para praktisi. Pemilihan topik Analisis Komponnen Utama dan Analisis Faktor dilakukan dengan mempertimbangkan manfaat kedua metode tersebut untuk analis data pada bidang pendidikan, sebagai contoh untuk analisis validitas konstruk dari instrumen penelitian. Hal ini sesuai dengan kondisi para peserta yang kebanyakan mahasiswa S2 pendidikan matematika.

Bahan workshop dibuat dalam bentuk modul dan diupload secara online melalui whatsapp. Hal ini mendukung gerakan paperless. Peserta dapat mendownload secara langsung modul dan melakukan praktik dengan mengikuti petunjuk yang ada di modul. Workshop dilaksanakan dengan lebih banyak porsi praktik oleh peserta dibandingkan dengan pemaparan teori, juga diskusi dan tanya jawab. Sehingga peserta dapat melakukan analisis dan menginterpretasikan sendiri hasil analisis. Pelatih memberikan panduan atau bimbingan, ketika ada peserta yang kesulitan atau kurang memahami proses analisis.

Secara umum dapat dikatakan workshop dapat berjalan dengan lancar dan sesuai harapan. Karena seting workshop lebih banyak praktiknya dengan modul yang lengkap, maka peserta tidak bosan dan antusias dalam mengikuti workshop hingga selesai. Peserta workshop berasal dari berbagai perguruan tinggi di seluruh
Indonesia, sehingga diharapkan ilmu yang didapat tidak hanya berguna bagi peserta workshop, tetapi juga akan dapat disebarluaskan di tempat asal masingmasing. Dari pelatihan ini diharapkan para pengguna statistika akan mengenal dan terbiasa menggunakan program tak berbayar $\mathrm{R}$ dibandingkan program-program lain yang berbayar, tanpa khawatir akan lisensi dari software.

\section{KESIMPULAN}

Berdasarkan evaluasi proses dan produk serta diskusi dengan peserta pelatihan kegiatan PPM dapat disimpulkan bahwa:

1. Seluruh pemuda Kampung Pingit peserta kegiatan pengasuhan manajemen kewirausahaan mengungkap bahwa kegiatan PPM tentang cara pembuatan sabun mandi aroma terapi dari limbah kulit jeruk dapat memberikan bekal pengetahuan dan pemahaman tentang pembuatan sabun mandi aroma terapi.

2. Sebanyak $100 \%$ peserta pelatihan menyatakan bahwa kegiatan pengasuhan manajemen kewirausahaan pengolahan limbah kulit jeruk menjadi sabun mandi aroma terapi dapat memberikan manfaat kepada mereka.

3. Sebanyak $91 \%$ peserta pelatihan menyatakan bahwa kegiatan pengasuhan manajemen kewirausahaan ini mampu memotivasi pemuda Kampung Pingit untuk mencoba sendiri dan sebanyak $80 \%$ peserta pelatihan menyatakan bahwa kegiatan PPM tersebut dapat memotivasi mereka untuk berwirausaha membuat usaha pembuatan sabun mandi aroma terapi.

Berdasarkan hasil evaluasi dan diskusi dengan peserta maka kegiatan pengabdian ini perlu ditindaklanjuti dengan kegiatan teknik membuat parfum dan sabun cair, membuat produk bervariasi menggunakan ekstrak tanaman/sayuran lainnya, pengembangan produk dengan alat dan bahan yang murah, sosialisasi lebih rutin dengan khalayak sasaran ibu rumah 
tangga dan masyarakat lainnya, serta disiapkan wadah khusus untuk pemasaran produk.

\section{UCAPAN TERIMA KASIH}

Ucapan terima kasih disampaikan kepada Fakultas MIPA UNY atas bantuan dana yang diberikan.

\section{PUSTAKA}

Badan Pusat Statistik. (2010). Sensus Penduduk 2010. Diakses dari www.bps.go.id. pada 20 Maret 2017 pukul 11.15 WIB

Kemenperin RI. 2016. Kemenperin Mengembangkan Wirausaha Baru yang Berdaya Saing Global. Diakses dari www.kemenperin.go.id pada 21 Maret 2017 pukul 09.00 WIB.

Taronto Foundation. 2015. Taronto Foundation Mendukung Pemerintah Indonesia dalam Meningkatkan Kewirausahaan. Diakses dari www.tanotofoundation.org pada 24 Maret 2017 pukul 21.00 WIB.

Riki Yakub. 2015. Kewirausahaan di Indonesia Mempengaruhi

Perekonomian. Diakses dari kompasiana.com pada 21 Maret 2017 pada pukul $15.00 \mathrm{WIB}$.

Sharma, S. 2009. Aromaterapi. Kharisma Publishing Group. Tangerang
Istianto, M. dan Muryati. 2014. Minyak Atsiri Jeruk: Manfaat dan Potensi Peningkatan Nilai Ekonomi Limbah Kulit Jeruk. Balitbang Pertanian. Kementerian Pertanian RI.

Fomari, T., Vicente, G., Vazquez, E., Garcia-Risco, M. R., and Roglero, G.. 2012. Isolation of Essential Oil from Different Plants and Herbs by Supercritical Fluid Extraction. Journal of Chromatography A. Volume 1250, p. 34-48.

Haminuddin, Soegijarto, dan Wiratni. 2010. Produksi Minyak Atsiri dari Limbah Kulit Jeruk Pontianak dengan Cara Cold Press. Jurnal Sistem Teknik. Volume 1.

Muchlis Bastian. 2015. Sabun Aromaterapi dari Kulit Jeruk. Diakses dari kompasiana.com pada 24 Maret pukul 20.00 WIB

Siswati, S., Nyoman Puspa Sari, Dwi Saptati, A. S., dan Diah Agustina P. 2016. Enfleurage essential Oil from Jasmina and Rose using Cold Fat Adsorbent. Jurnal Ilmiah Widya Teknik. Volume 15. Nomor 1, p. 5861.

Susanto, T. R. dan Saroh, M.F. 2013. Produksi Minyak Atsiri dari Limbah Kulit Jeruk Manis dengan Destilasi Uap. Laporan Penelitian Ilmiah. http://prezi.com pada 25 Maret 2017 $\begin{array}{lll}\text { pukul } & 20.00 & \text { WIB. }\end{array}$ 